\title{
APPLICATION OF HYPERSPECTRAL IMAGING FOR CULTIVAR DISCRIMINATION OF MALTING BARLEY GRAINS ${ }^{1}$
}

\author{
Piotr Zapotoczny, Ewa Ropelewska* \\ Department of Systems Engineering, Faculty of Engineering, \\ University of Warmia and Mazury in Olsztyn
}

"Corresponding author: e-mail: ewa.ropelewska@uwm.edu.pl

\begin{tabular}{|c|c|}
\hline ARTICLE INFO & ABSTRACT \\
\hline $\begin{array}{l}\text { Article history: } \\
\text { Received: February } 2016 \\
\text { Received in the revised form: } \\
\text { March } 2016 \\
\text { Accepted: April } 2016\end{array}$ & \multirow{2}{*}{$\begin{array}{l}\text { The aim of this study was to perform and evaluate the accuracy of } \\
\text { classification of grains of different cultivars of malting barley. The } \\
\text { grains of eight cultivars: Blask, Bordo, Conchita, Kormoran, Mer- } \\
\text { cada, Serwal, Signora, Victoriana, with three moisture content: 12, } \\
\text { 14, } 16 \% \text { were examined. The selected parameters of the surface } \\
\text { texture of grain mass obtained from images taken using the techniques } \\
\text { of hyperspectral imaging were determined. The accuracy of grains } \\
\text { discrimination carried out using different methods of selection and } \\
\text { classification of data was compared. The pairwise comparison and } \\
\text { comparison of three, four and eight cultivars of malting barley were } \\
\text { carried out. The most accurate discrimination was determined in the } \\
\text { case of the pairwise comparison. Victoriana cultivar was the most } \\
\text { different from the others. The most similar texture of grain mass was } \\
\text { found in the comparison of cultivars: Blask and Mercada. In the case } \\
\text { of eight examined cultivars of malting barley, the most accurate } \\
\text { discrimination (classification error - 55\%) was obtained for images } \\
\text { taken at the moisture content of } 14 \% \text { and at a wavelength of } 750 \text { nm, } \\
\text { for the attributes selection performed with the use of probability of } \\
\text { error and average correlation coefficient (POE+ACC) method and the } \\
\text { discrimination carried out using the linear discriminant analysis } \\
\text { (LDA). }\end{array}$} \\
\hline $\begin{array}{l}\text { Key words: } \\
\text { spring malting barley, } \\
\text { grain mass, } \\
\text { attributes selection, } \\
\text { multidimensional analysis, } \\
\text { classification error }\end{array}$ & \\
\hline
\end{tabular}

\section{Introduction}

Hyperspectral imaging is a noninvasive, nondestructive, simple, inexpensive for application and expeditious analytical technique (Sun, 2010). Hyperspectral images include numerous spatial planes of the tested sample at different wavelengths. As a result, the hypercube is achieved due to the superimposition of obtained spatial images. It is possible to carry out the qualitative or quantitative analysis of results in order to identify the relationships between properties of an object and its spectral characteristics. The qualitative analysis can be performed with the use of, inter alia, linear discriminant analysis (LDA), princi-

1 This study was financed by grant No. PBS3/A8/38/2015 from the National Centre for Research and Development.

The authors would like to thank Damian Manerowski for help in performing the studies. 
ple component analysis (PCA), partial least squares discriminant analysis (PLSDA), $\mathrm{k}$-means clustering, manual observation. These tools allow for discrimination of the studied objects according to the assumed selection criterion. In the case of quantitative analysis of the obtained dimensional data, the PCA, partial least squares regression (PLSR), stepwise multi-linear regression (SMLR), support vector machines (SVM), least square support vector machines (LS-SVM) are applied. These methods can be used for prediction of chemical content, determination of food quality (Huang et al., 2014).

Hyperspectral imaging is a useful instrument used in food analysis (Gowen et al., 2007). It allows to obtain spatial and spectral information from the range of visible light, farinfrared, near-infrared, ultraviolet and microwaves (Gowen et al., 2007; Sun, 2010). In this way, it has the advantages over the conventional computer imaging systems. Hyperspectral analysis can be applied in the discrimination of classes cereals (Mahesh et al., 2008), to evaluate the quality of the bulk material by identification of the contaminants in the sample (Wallays et al., 2009; Pierna et al., 2012), to identify the cereal grains infected by the fungi (Shahin and Symons, 2011; Williams et al., 2012). Hyperspectral imaging allows the determination of shape, size, hardness, surface texture, color, moisture content, protein content, oil content, vitreousness of grains. Additionally, this technique enables detection of the presence of varietal impurities, sprouted, fungal-infected, insect-damaged, discolored kernels and the determination of reflectance, fluorescence, phosphorescence transmittance and light absorption coefficients (Sun, 2010).

The aim of this study was to evaluate the classification of grains belonging to different cultivars of malting barley. The analyses were performed based on the selected parameters of the surface texture of grain mass obtained from images taken using the techniques of hyperspectral imaging. The accuracy of discrimination carried out using different methods of selection and classification of data was compared.

\section{Material and methods}

The experimental material comprised grains of spring malting barley obtained from Hodowla Roślin Strzelce Sp. z o.o. Grupa IHAR, Poland. Twenty four experimental groups containing grains of eight cultivars: Blask, Bordo, Conchita, Kormoran, Mercada, Serwal, Signora, Victoriana, with three moisture content: 12, 14, 16\% were examined.

The moisture content of barley grains was determined according to the Polish standard PN-EN ISO 712:2012. The initial moisture of grains was approx. 11\%. Conditioning treatment was carried out in order to obtain 12,14 and $16 \%$ of moisture content. The appropriate amount of water, which should be added to grains was calculated using Duwal formula (1) (Jakubczyk and Haber, 1981):

$$
Q_{w}=Q_{z} \cdot \frac{W_{k}-W_{p}}{100-W_{k}}
$$

where:

$Q_{w} \quad$ - the amount of water, which should be added to achieve the expected moisture content, $\left(\mathrm{kg}_{\text {or }} \mathrm{m}^{3}\right)$

$Q_{z} \quad$ - mass of grains before addition of water, $(\mathrm{kg})$

$W_{p} \quad-$ initial moisture content of grains, (\%)

$W_{k} \quad-$ final (required) moisture content of grains, (\%) 
Application of hyperspectral imaging...

Grains with an appropriate amount of water were placed in a rotating container $\left(5 \mathrm{dm}^{3}\right)$ for 24 hours. After this period of time, the moisture content of barley grains was determined once again.

In the studies, a laboratory stand for hyperspectral photography in the range of VIS/NIR 400-1000 nm and SpecHyp software to analyze the obtained images were used. The images for grain mass (fig. 1) of spring malting barley were obtained.

For all experimental groups the images at four wavelengths: 550, 650, 750, $900 \mathrm{~nm}$ were isolated and in the case of all images several regions of interest (ROI) were selected (Fig. 2).

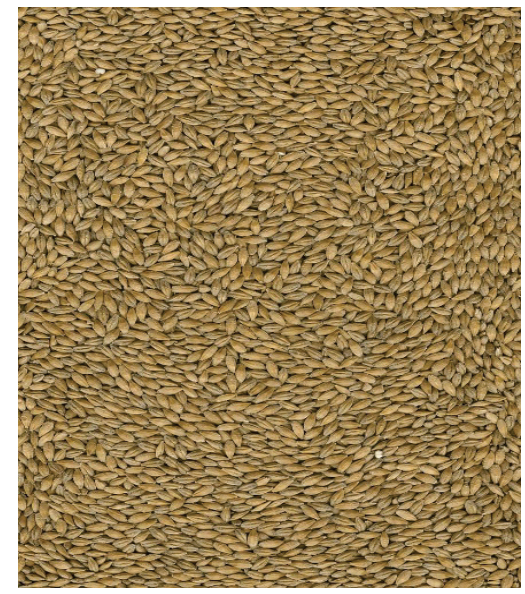

Figure 1. Grain mass of spring malting barley

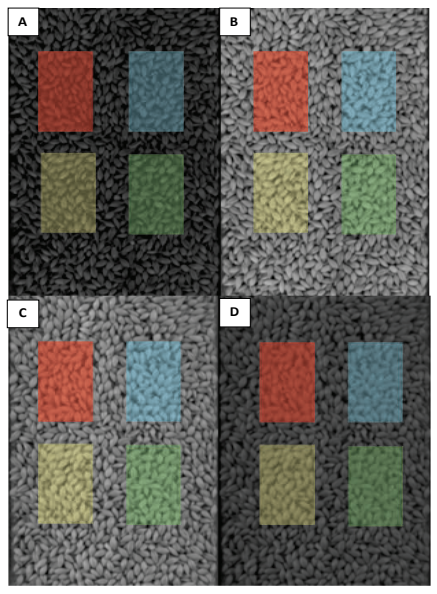

Figure 2. Selected images of malting barley grains, Bordo cultivar, at the moisture content of $12 \%$, at different wavelengths: $A-550 \mathrm{~nm}, B-650 \mathrm{~nm}, C-750 \mathrm{~nm}, D-900 \mathrm{~nm}$

Discriminant analysis was performed according to the method described by Zapotoczny (2009). In the first stage of the analysis, the attributes selection was carried out with the use of MaZda v. 4.6 software (Technical University of Lodz, Institute of Electronics, Poland), using 4 methods: Fisher coefficient (F), probability of error and average correlation coefficient (POE $+\mathrm{ACC}$ ), mutual information coefficient (MI), a combination of three methods: $\mathrm{MI}+\mathrm{PA}+\mathrm{F}$. The second step was performed using the B11 program (Technical University of Lodz, Institute of Electronics, Poland). Multidimensional analyses with the use of 3 methods: linear discriminant analysis (LDA), non-linear discriminant analysis (NDA), principal component analysis (PCA) were performed. The criterion for the evaluation of analysis was the smallest classification error. 
Piotr Zapotoczny, Ewa Ropelewska

\section{Results}

The pairwise comparison of malting barley cultivars was carried out. Victoriana cultivar was the most distinguished from the others. The mean error of the classification of this cultivar was $3.3 \%$ and for comparison with the Signora cultivar, error of $0.0 \%$ was obtained. The highest classification error $(46.5 \%)$ was noted for comparison of cultivars: Blask and Mercada, which indicates the most similar texture of grain mass (table 1).

Table 1.

Classification error (\%) for pairwise comparisons of malting barley cultivars (moisture content of $14 \%$; wavelength of $750 \mathrm{~nm} ; \mathrm{POE}+A C C$; $L D A$ )

\begin{tabular}{|c|c|c|c|c|c|c|c|c|c|}
\hline & $\frac{\frac{y}{\pi}}{\frac{\pi}{n}}$ & 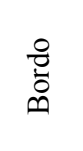 & $\begin{array}{l}\frac{\pi}{0} \\
0 \\
0 \\
0\end{array}$ & 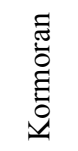 & $\sum_{\substack{\frac{\pi}{0} \\
\frac{\pi}{0}}}^{\frac{\pi}{2}}$ & 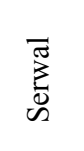 & 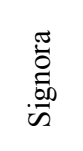 & 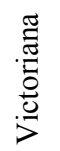 & $\begin{array}{c}\text { Mean error of } \\
\text { classification } \\
(\%)\end{array}$ \\
\hline Blask & $\mathrm{X}$ & 40.0 & 43.2 & 36.3 & $\underline{46.5}$ & 35.9 & 25.2 & 5.5 & 33.2 \\
\hline Bordo & 40.0 & $X$ & 38.1 & 40.8 & 28.3 & 31.1 & 31.1 & 1.0 & 30.1 \\
\hline Conchita & 43.2 & 38.1 & $X$ & 39.5 & 33.8 & 32.4 & 17.4 & 3.3 & 29.7 \\
\hline Kormoran & 36.3 & 40.8 & 39.5 & $\mathrm{X}$ & 39.5 & 40.4 & 33.6 & 2.5 & 33.2 \\
\hline Mercada & $\underline{46.5}$ & 28.3 & 33.8 & 39.5 & $\mathrm{X}$ & 32.4 & 22.1 & 5.7 & 29.7 \\
\hline Serwal & 35.9 & 31.1 & 32.4 & 40.4 & 32.4 & $X$ & 16.6 & 5.5 & 27.8 \\
\hline Signora & 25.2 & 31.1 & 17.4 & 33.6 & 22.1 & 16.6 & $\mathrm{X}$ & $\underline{0.0}$ & 20.8 \\
\hline Victoriana & 5.5 & 1.0 & 3.3 & 2.5 & 5.7 & 5.5 & $\underline{0.0}$ & $X$ & 3.3 \\
\hline
\end{tabular}

According to the obtained scatterplot (Figure 3), the cultivars Signora and Victoriana were completely separated.

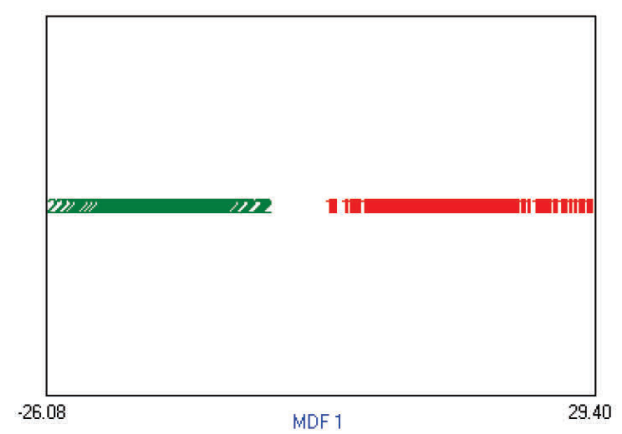

Figure 3. Scatterplot for discriminant analysis of two malting barley cultivars: Signora and Victoriana, at the moisture content of $14 \%$, using LDA, for the variables selected by $P O E+A C C$ method, the wavelength of $750 \mathrm{~nm}$ 
Application of hyperspectral imaging...

Distribution of cases from discriminant analysis of 3 malting barley cultivars, for which the smallest mean error of classification was noted: Victoriana, Signora, Serwal is shown in figure 4 .

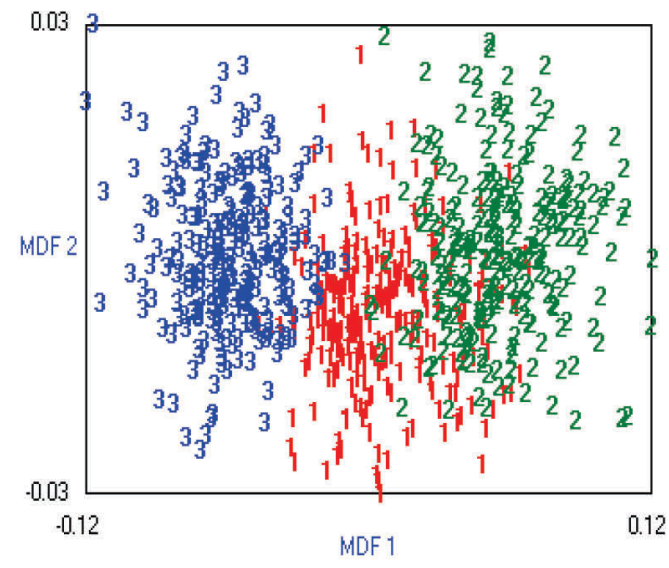

Figure 4. Distribution of cases from discriminant analysis of 3 malting barley cultivars: Victoriana, Signora, Serwal, at the moisture content of $14 \%$, using $L D A$, for the variables selected by $P O E+A C C$ method, the wavelength of $750 \mathrm{~nm}$

In the case of three cultivars the error was $15.9 \%$. After introduction of an additional cultivar, the classification error was higher more than twice (tab. 2).

Table 2.

Classification error of malting barley cultivars based on the texture of grain mass, the wavelength of $750 \mathrm{~nm}$

\begin{tabular}{lc}
\hline Cultivars & Classification error (\%) \\
\hline Serwal, Signora, Victoriana & 15.9 \\
Serwal, Signora, Victoriana, Blask & 36.7 \\
Serwal, Signora, Victoriana, Bordo & 32.7 \\
Serwal, Signora, Victoriana, Conchita & 34.6 \\
Serwal, Signora, Victoriana, Kormoran & 36.9 \\
Serwal, Signora, Victoriana, Mercada & 35.6 \\
\hline
\end{tabular}

In the case of images obtained at the wavelength of $550 \mathrm{~nm}$, the mean error of the classification was $77.6 \%$. The smallest classification error was observed for combination of the methods of the attributes selection, linear discriminant analysis and at the moisture content of $16 \%$. The highest error of $92.8 \%$ was reported for POE+ACC, NDA, the moisture content of $12 \%$ (tab. 3 ).

One of the cultivars (7) was farthest from the others, and it was most different from the eighth cultivar (fig. 5). 
Piotr Zapotoczny, Ewa Ropelewska

Table 3.

Classification error of malting barley cultivars based on the texture of grain mass, the wavelength of $550 \mathrm{~nm}$

\begin{tabular}{|c|c|c|c|c|c|c|c|c|c|c|c|c|}
\hline \multicolumn{13}{|c|}{ Classification error of malting barley cultivars, $(\%)$} \\
\hline \multirow{2}{*}{ 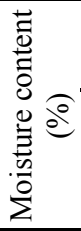 } & \multicolumn{3}{|c|}{$\begin{array}{l}\text { Fisher } \\
\text { coefficient }\end{array}$} & \multicolumn{3}{|c|}{$\mathrm{POE}+\mathrm{ACC}$} & \multicolumn{3}{|c|}{ MI } & \multicolumn{3}{|c|}{$\mathrm{MI}+\mathrm{PA}+\mathrm{F}$} \\
\hline & $\underset{\varrho}{\longleftarrow}$ & $\overleftrightarrow{\leftrightarrows}$ & 吕 & 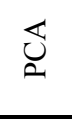 & 㟔 & 䒘 & せ্ర & $\overleftrightarrow{\Xi}$ & 岂 & せ্ট & 㟔 & 艺 \\
\hline 12 & 77.7 & 66.1 & 92.7 & 79.1 & 62.2 & $\underline{92.8}$ & 72.7 & 66.5 & 92.6 & 79.3 & 60.6 & 92.0 \\
\hline 14 & 75.9 & 72.7 & 91.0 & 78.4 & 74.4 & 90.7 & 77.3 & 76.2 & 92.2 & 81.8 & 67.00 & 89.8 \\
\hline 16 & 70.6 & 63.4 & 82.0 & 88.6 & 67.2 & 88.0 & 69.1 & 69.1 & 83.8 & 72.3 & 58.8 & 80.6 \\
\hline
\end{tabular}

A

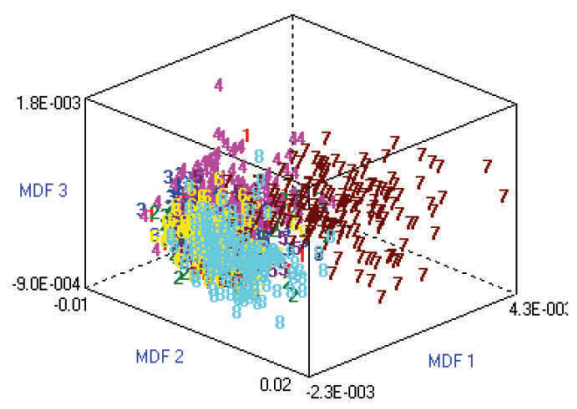

B

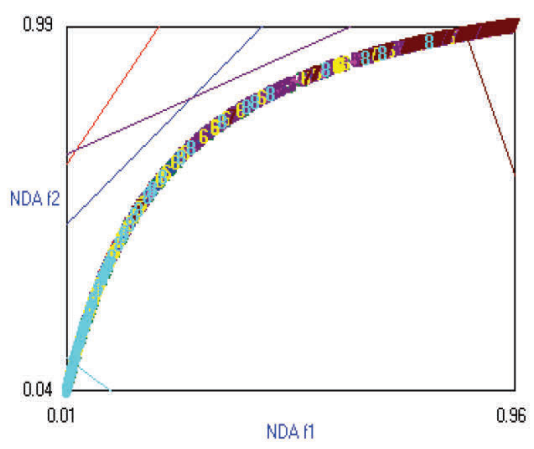

Figure 5. Scatterplot for discriminant analysis of 8 malting barley cultivars for the wavelength of $550 \mathrm{~nm}$ at the moisture content of $16 \%$, using LDA, for the variables selected by $M I+P A+F(A)$ and at the moisture content of $12 \%$, using NDA, for the variables selected by probability of error and average correlation coefficient $(P O E+A C C)(B)$

For classification based on the texture of grain mass at the wavelength of $650 \mathrm{~nm}$ the mean error of $74.5 \%$ was the smallest of all wavelengths. The smallest classification error was observed for POE $+\mathrm{ACC}$ method of attribute selection, linear discriminant analysis, moisture content of $16 \%$ and the highest error was obtained in the case of Fisher coefficient, NDA, moisture content of $14 \%$ (tab. 4). A cultivar, which completely differs from the others was not found (fig. 6). 
Application of hyperspectral imaging...

Table 4

Classification error of malting barley cultivars based on texture of grain mass, the wavelength of $650 \mathrm{~nm}$

\begin{tabular}{|c|c|c|c|c|c|c|c|c|c|c|c|c|}
\hline \multirow{3}{*}{ 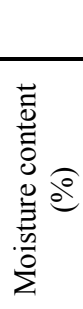 } & \multicolumn{12}{|c|}{ Classification error of malting barley cultivars, $(\%)$} \\
\hline & \multicolumn{3}{|c|}{$\begin{array}{l}\text { Fisher } \\
\text { coefficient }\end{array}$} & \multicolumn{3}{|c|}{$\mathrm{POE}+\mathrm{ACC}$} & \multicolumn{3}{|c|}{ MI } & \multicolumn{3}{|c|}{$\mathrm{MI}+\mathrm{PA}+\mathrm{F}$} \\
\hline & હ્ટ & $\overleftrightarrow{G}$ & 穵 & 芯 & $\overleftrightarrow{G}$ & 艺 & 远 & $\overleftrightarrow{\text { 亗 }}$ & 穵 & 岕 & 亗 & 穵 \\
\hline 12 & 73.4 & 72.9 & 86.8 & 75.7 & 62.7 & 86.7 & 72.0 & 67.9 & 86.4 & 74.0 & 60.1 & 85.8 \\
\hline 14 & 75.6 & 72.4 & $\underline{86.9}$ & 76.8 & 69.2 & 85.4 & 75.6 & 72.2 & 86.4 & 71.4 & 67.1 & 84.2 \\
\hline 16 & 67.0 & 65.5 & 81.9 & 69.2 & $\underline{59.2}$ & 81.5 & 67.8 & 67.3 & 82.4 & 69.5 & 61.0 & 80.0 \\
\hline
\end{tabular}

A

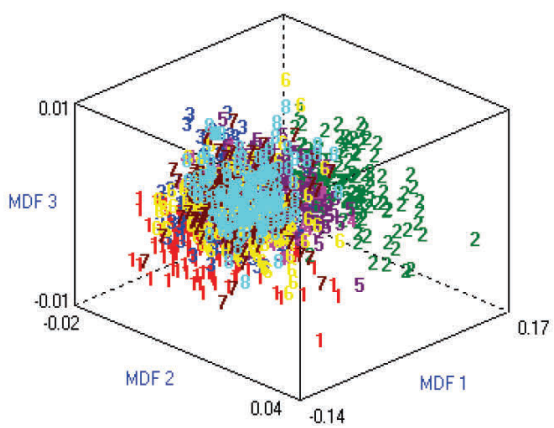

B

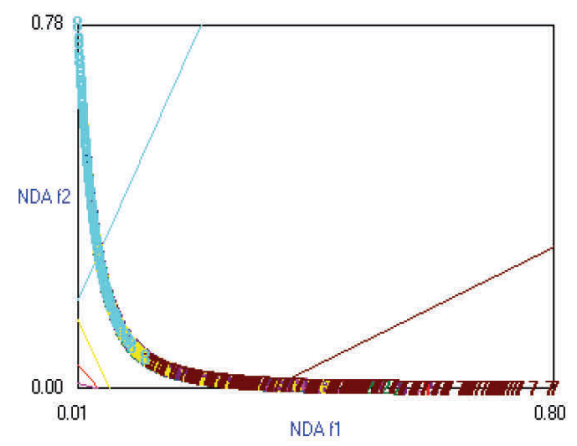

Figure 6. Scatterplot for discriminant analysis of 8 malting barley for the wavelength of $650 \mathrm{~nm}$ cultivars at the moisture content of $16 \%$, using LDA, for the variables selected by $P O E+A C C$ method (A) and at the moisture content of $14 \%$, using NDA for the variables selected by Fisher coefficient $(F)(B)$

In the case of $750 \mathrm{~nm}$ wavelength, the moisture content of $14 \%$, attributes selection: POE $+\mathrm{ACC}$, and the linear discriminant analysis (LDA), the most accurate discrimination (error of 55\%) among discrimination of eight examined cultivars of malting barley was obtained. But it was a very unsatisfactory result. The highest error was noted for the wavelength of $650 \mathrm{~nm}$ in the case of Fisher coefficient, NDA, moisture content of $12 \%$. The mean error of classification of all analyzes at the wavelength of $750 \mathrm{~nm}$ was $77.3 \%$ (tab. 5). Individual variations did not create separate clusters on the obtained graphs (fig. 7). 
Piotr Zapotoczny, Ewa Ropelewska

Table 5.

Classification error of malting barley cultivars based on texture of grain mass, the wavelength of $750 \mathrm{~nm}$

\begin{tabular}{|c|c|c|c|c|c|c|c|c|c|c|c|c|}
\hline & \multicolumn{12}{|c|}{ Classification error of malting barley cultivars, $(\%)$} \\
\hline \multirow{2}{*}{ 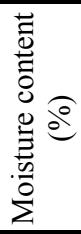 } & \multicolumn{3}{|c|}{$\begin{array}{l}\text { Fisher } \\
\text { coefficient }\end{array}$} & \multicolumn{3}{|c|}{$\mathrm{POE}+\mathrm{ACC}$} & \multicolumn{3}{|c|}{ MI } & \multicolumn{3}{|c|}{$\mathrm{MI}+\mathrm{PA}+\mathrm{F}$} \\
\hline & $\bigcup_{0}$ & 㟔 & 穵 & $\bigcup_{2}^{\mathbb{2}}$ & 㟔 & 穵 & 导 & 㟔 & 尽 & ঠ્ટ & 㟔 & 穵 \\
\hline 12 & 73.3 & 73.2 & $\underline{90.6}$ & 88.4 & 74.1 & 90.2 & 70.6 & 73.6 & 89.4 & 73.4 & 64.6 & 88.7 \\
\hline 14 & 72.3 & 72.3 & 85.2 & 71.9 & $\underline{55.0}$ & 84.5 & 69.8 & 71.9 & 84.7 & 73.1 & 61.1 & 88.2 \\
\hline 16 & 73.5 & 75.0 & 86.1 & 75.6 & 68.8 & 86.5 & 73.0 & 71.5 & 85.9 & 73.3 & 62.8 & 85.2 \\
\hline
\end{tabular}

A

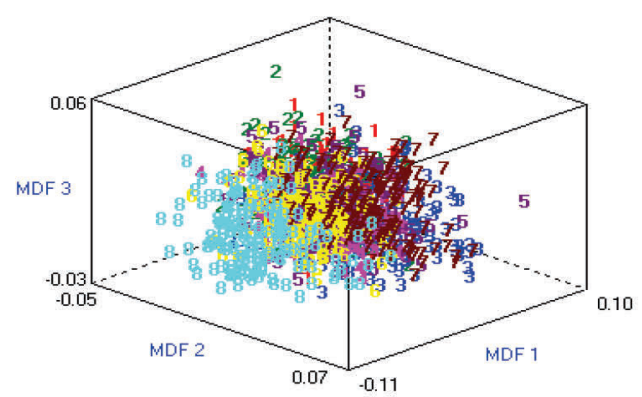

$\mathrm{B}$

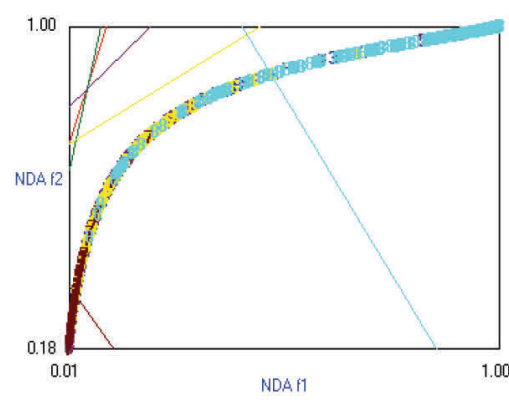

Figure 7. Scatterplot for discriminant analysis of 8 malting barley cultivars for the wavelength of $750 \mathrm{~nm}$, at the moisture content of $14 \%$, using LDA, for the variables selected by probability of error and average correlation coefficient $(A)$ and at the moisture content of $12 \%$, using NDA, for the variables selected by Fisher coefficient $(F)(B)$

For wavelength of $900 \mathrm{~nm}$ the mean error was $79.7 \%$, the smallest classification error of 61.3 was observed for POE+ACC, LDA, moisture content of $16 \%$. The highest error of $92.4 \%$ was reported for MI, NDA, the moisture content of $12 \%$ (tab. 6). Cultivars creating separate clusters on the graphs were not found (fig. 8). 
Application of hyperspectral imaging...

Table 6.

Classification error of malting barley cultivars based on texture of grain mass, the wavelength of $900 \mathrm{~nm}$

\begin{tabular}{|c|c|c|c|c|c|c|c|c|c|c|c|c|}
\hline \multicolumn{13}{|c|}{ Classification error of malting barley cultivars, $(\%)$} \\
\hline \multirow{2}{*}{ 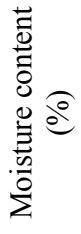 } & \multicolumn{3}{|c|}{$\begin{array}{c}\text { Fisher } \\
\text { coefficient }\end{array}$} & \multicolumn{3}{|c|}{$\mathrm{POE}+\mathrm{ACC}$} & \multicolumn{3}{|c|}{ MI } & \multicolumn{3}{|c|}{$\mathrm{MI}+\mathrm{PA}+\mathrm{F}$} \\
\hline & ঠ্口 & 㟔 & 甾 & ঠ્ટ & $\overleftrightarrow{\text { G }}$ & 艺 & 屯্ & 岕 & 穵 & $\bigcup_{0}$ & 㟔 & 穵 \\
\hline 12 & 79.2 & 78.1 & 92.3 & 80.4 & 70.1 & 91.6 & 74.9 & 76.8 & $\underline{92.4}$ & 81.1 & 68.4 & 90.9 \\
\hline 14 & 75.7 & 74.9 & 89.9 & 77.6 & 61.6 & 89.1 & 75.8 & 76.5 & 90.0 & 78.1 & 66.3 & 89.5 \\
\hline 16 & 76.5 & 75.9 & 89.8 & 77.0 & 61.3 & 89.3 & 74.8 & 77.4 & 89.9 & 78.0 & 69.0 & 89.5 \\
\hline
\end{tabular}

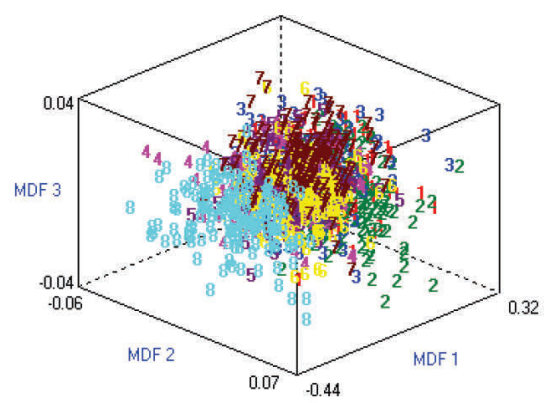

B

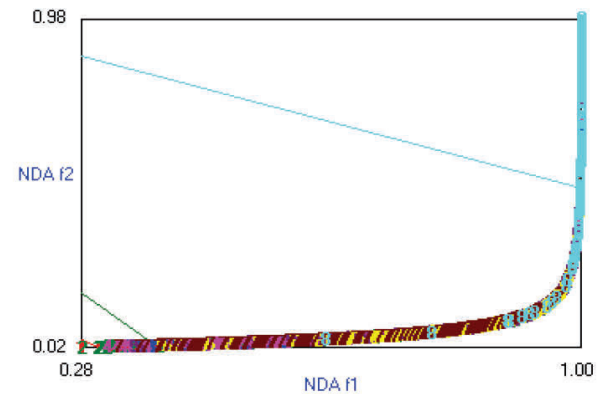

Figure 8. Scatterplot for discriminant analysis of 8 malting barley cultivars for the wavelength of $900 \mathrm{~nm}$, at the moisture content of $16 \%$, using LDA, for the variables selected by $P O E+A C C$ method (A) and at the moisture content of $12 \%$, using NDA, for the variables selected by mutual information coefficient $(B)$

\section{Conclusions}

The most accurate discrimination between all examined cultivars of malting barley was obtained in the case of images of grain mass at the moisture content of $14 \%$ and at the wavelength of $750 \mathrm{~nm}$. The attributes selection was carried out with the use of POE+ACC method and the discrimination - using the linear discriminant analysis (LDA). The obtained classification error was $55 \%$ and it was a very unsatisfactory result. A similar method of analysis results was used for pairwise comparisons between each of all the cultivars. Victoriana cultivar was the most distinguished from the others. The mean error of the classifica- 
tion of this cultivar was 3.3\% and for comparison with the Signora cultivar, error of $0.0 \%$ was obtained. The highest classification error (46.5\%) was reported for comparison of cultivars: Blask and Mercada, which indicates the most similar texture of grain mass.

\section{References}

Gowen, A.A., O'Donnella, C.P., Cullen, P.J., Downey, G., Frias, J.M. (2007). Hyperspectral imaging - an emerging process analytical tool for food quality and safety control. Trends in Food Science and Technology, 18, 590-598.

Huang, H., Liu, L., Ngadi, M.O. (2014). Recent Developments in Hyperspectral Imaging for Assessment of Food Quality and Safety. Sensors, 14, 7248-7276.

Jakubczyk, T., Haber, T. (1981). Analiza zbóż i przetworów zbożowych. SGGW-AR, Warszawa.

Mahesh, S., Manickavasagan, A., Jayas, D.S., Paliwal, J., White, N.D.G. (2008). Feasibility of nearinfrared hyperspectral imaging to differentiate Canadian wheat classes. Biosystems Engineering, 10, 50-57.

Pierna, J.A.F., Vermeulen, P., Amand, O., Tossens, A., Dardenne, P., Baeten, V. (2012). NIR hyperspectral imaging spectroscopy and chemometrics for the detection of undesirable substances in food and feed. Chemometrics and Intelligent Laboratory Systems, 117, 233-239.

PN-EN ISO 712:2012. Ziarno zbóż i przetwory zbożowe - Oznaczanie wilgotności - Metoda odwotawcza.

Shahin, M.A., Symons, S.J. (2011). Detection of Fusarium damaged kernels in Canada Western Red Spring wheat using visible/near-infrared hyperspectral imaging and principal component analysis. Computers and Electronics in Agriculture, 75, 107-112

Sun, D.W. (2010). Hyperspectral Imaging for Food Quality Analysis and Control. Academic Press/Elsevier, San Diego, California, USA.

Wallays C., Missotten B., De Baerdemaeker J., Saeys W. (2009). Hyperspectral waveband selection for on-line measurement of grain cleanness. Biosystems Engineering, 104, 1-7.

Williams, P.J., Geladi, P., Britz, T.J., Manley, M. (2012). Investigation of fungal development in maize kernels using NIR hyperspectral imaging and multivariate data analysis. Journal of Cereal Science, 55, 272-278.

Zapotoczny, P. (2009). Dyskryminacja odmian ziarna pszenicy na podstawie cech geometrycznych. Agricultural Engineering, 5(114), 319-328. 
Application of hyperspectral imaging...

\section{ZASTOSOWANIE OBRAZOWANIA HIPERSPEKTRALNEGO DO DYSKRYMINACJI ODMIANOWEJ ZIAREN JECCZMIENIA BROWARNEGO}

Streszczenie. Celem pracy było przeprowadzenie i ocena poprawności klasyfikacji ziaren należących do różnych odmian jęczmienia browarnego. Przebadano ziarna 8 odmian: Blask, Bordo, Conchita, Kormoran, Mercada, Serwal, Signora, Victoriana, o trzech poziomach wilgotności: 12, 14, 16\%. Oznaczono wybrane parametry tekstury powierzchni ziarna w masie uzyskane ze zdjęć wykonanych przy użyciu technik obrazowania hiperspektralnego. Porównano dokładność dyskryminacji ziaren przeprowadzonej przy użyciu różnych metod selekcji i klasyfikacji danych. Dokonano porównania parami oraz porównania trzech, czterech i ośmiu odmian jęczmienia browarnego. Najbardziej dokładną dyskryminację stwierdzono w przypadku porównania parami. Odmiana Victoriana najbardziej odróżniała się od innych. Najbardziej podobną teksturę ziaren w masie stwierdzono w przypadku porównania odmian: Blask i Mercada. W przypadku ośmiu badanych odmian jęczmienia browarnego, najdokładniejszą dyskryminację (błąd klasyfikacji - 55\%) uzyskano dla obrazów wykonanych przy wilgotności 14\% i długości fali $750 \mathrm{~nm}$, dla selekcji atrybutów wykonanej z wykorzystaniem prawdopodobieństwa błędu klasyfikacji z uśrednionym współczynnikiem korelacji (POE + ACC) oraz dyskryminacji przeprowadzonej za pomocą liniowej analizy dyskryminacyjnej (LDA).

Słowa kluczowe: jęczmień jary browarny, masa ziarna, selekcja atrybutów, analiza wielowymiarowa, błąd klasyfikacji 